another, and which for that reason would not last.

Such a modest agenda might even persuade President George Bush to take time out from his election campaign to attend, as the president of Brazil, Fernando Collor de Mello, has been urging. Bush's obvious disinclination is no doubt partly inspired by the fear of being trapped into rejecting demands for specific restraints on fossil fuel consumption in the months before a election. But electoral considerations (and the chance that there might be a few green votes to be picked up) might similarly have him on the way to Rio to lend support to the framework of an undertaking to act responsibly, in the interests of the world's environment, if and when the basis of responsible action has been defined. And the plain truth is that no agreement on global warming will be worth having unless it includes the United States (not to mention China and the states of the Commonwealth of Independent States). It will be a great shame if the opportunity of Rio is lost because the enthusiasts have attempted too much.

\section{Another election soon}

Flurries of interest in science towards the end of Britain's election campaign promise little, but another election may.

THE best thing to say about the British general election campaign that ends today (9 April) with an election is that it may have to be repeated very soon. The polls, which suggest that there will be a change of government, also agree that the new government's majority will be only small, and may not even be absolute. Only next week will it become possible to tell whether the new government has been able to muster enough support to last for a reasonable length of time. Under the British system, there could be another election in just a month, but the chances are that everybody is too bored (and party funds too depleted) for that to be possible. But another election in a few months would at least bring into the open the questions buried during the past few weeks of cautious campaigning.

One of these was science. Only towards the end of a contrived campaign did the issue come to life in any form, and then only because the government was provoked into responding to criticisms by the pressure group "Save British Science" and by various round robins carrying the signatures of researchers and academics. Poor Mr Allan Haworth, the minister at the Department of Education and Science with responsibility for higher education and research, was forced into several repetitions of the government's line that there is nothing wrong with the British research enterprise; how could there be, when the public funds available have been increased faster than inflation, and when Britain has "the best university system in Western Europe"? It is to be hoped that by the time the next election comes around, the complacency of $\mathrm{Mr}$ Haworth's party will have been punctured by the nowpublic testaments of British academics to the demoralization that they share.

Before the next election, it is also important that Britain should learn more about the plans of the two major parties on technical and vocational education, their common recipe for the improvement of the competitiveness of British industry. (The recipes differ in that the Conservative Party offers training vouchers to students not staying on for higher education, would offer vocational examinations to those still at school and would otherwise work through existing Technical Education Councils; the Labour party would develop a "coherent" programme.) What neither party seems fully to appreciate is that industrial competitiveness also requires a cadre of people educated in the methods of research and capable of fostering radical innovation. The demoralization of the research enterprise brought about in the past dozen years is unlikely to increase the supply of such people.

\section{Bring back Tsongas}

US presidential candidates should either forget science or learn a little, if a calamitous forum last week is any guide.

IF only US science could be simply ignored by political candidates, as British science has been. If there had been no mention of it by the presidential hopefuls, it might have been possible to imagine that each cares a little about research, but realizes that there are no votes to be won from common folk by touting it on the campaign trail. But, as luck will have it, the silence - ignorant or otherwise - has not lasted.

Last week, the Council on Research and Technology (Coretech) asked the presidential candidates to describe their positions on science and technology (via representatives) at a special forum in Washington. Three-Mr Jerry Brown, Governor Bill Clinton and President George Bush - complied. For anyone who still thinks that research is at least as important a political issue as bounced checks, the occasion was neither edifying nor reassuring.

Brown was represented by a Baptist reverend from Detroit named Horace Hilsman, who wanted to know why "the AIDS cure in Africa" is being suppressed. Bush's representative, Ms Deborah Wince-Smith, who once campaigned for President Ronald Reagan and who is now assistant secretary for technology policy in the Department of Commerce, let her allegiance show by crediting "President Reagan" with having launched her own agency's National Technology Initiative last year. And Clinton's man momentarily overlooked allegations of scandal against his master when he assured questioners (asking for a position on research issues such as indirect costs and misconduct) that Clinton "is opposed to abuses of all kinds".

This pathetic showing will make for difficult choices at election time in November: vote for Clinton, whose representative embarrassed himself least, or Pat Buchanan, who sent no one at all? If Texas industrialist $\mathrm{H}$. Ross Perot (who has a long track record of research advocacy) enters the race, choice may be simplified. But the best hope may be for Paul Tsongas to re-enter the race. 